Relations industrielles

Industrial Relations

\title{
Ratnam, C.S. Venkata, Gerd Botterweck and Pravin Sinha, eds., Labour and Unions in a Period of Transition
}

\section{Abdul Gani}

Volume 52, numéro 3, 1997

URI : https://id.erudit.org/iderudit/051197ar

DOI : https://doi.org/10.7202/051197ar

Aller au sommaire du numéro

Éditeur(s)

Département des relations industrielles de l'Université Laval

ISSN

0034-379X (imprimé)

1703-8138 (numérique)

Découvrir la revue

Citer ce compte rendu

Gani, A. (1997). Compte rendu de [Ratnam, C.S. Venkata, Gerd Botterweck and Pravin Sinha, eds., Labour and Unions in a Period of Transition]. Relations industrielles / Industrial Relations, 52(3), 668-670.

https://doi.org/10.7202/051197ar

Tous droits réservés @ Département des relations industrielles de l'Université Laval, 1997
Ce document est protégé par la loi sur le droit d'auteur. L’utilisation des services d'Érudit (y compris la reproduction) est assujettie à sa politique d'utilisation que vous pouvez consulter en ligne.

https://apropos.erudit.org/fr/usagers/politique-dutilisation/ 


\section{Labour and Unions in a Period of Transition}

edited by C.S. Venkata RATNAM, Gerd BOTTERWECK and Pravin SinHA, New

Delhi : Friedrich Ebert Stiftung, 1994, 246 p.

The world economy is in a period of profound restructuring. While these restructuring programmes attempt to infuse new elements of dynamism to the growth process, these have brought about strategic changes in the context and process of industrial relations and raised many issues and concerns of serious consequences for government, employers, workers and trade unions. The changing nature of trade unions is one of the most widely and forcefully debated issues of labour relations today. As a theme for conferences and symposia, the subject appears to have been overworked. The book under review, however, is the first systematic and in-depth examination of some of the emerging developments and trends in Indian Trade Union Movement (ITUM). It is an outcome of a National Conference on "The Changing Role of Trade Unions in a Period of Transition" jointly organized by National Productivity Council, International Management Institute, ILO and Friedrick Ebert Stiftung in Delhi during May 1994. Friedrich Ebert Stiftung (FES), known for its commitment to social democracy and tremendous contribution to social development, labour relations, business, science and culture, has published this volume. In addition to the theme paper, report and post-script, the volume carries 9 papers presented and distributed at the conference. This book is distinctly different from most of the early works in India on the subject because every paper, embodied in a wealth of data and dense literature, is a vivid portrayal of the manifestations of the changing nature of ITUM.

Some brief comments on the papers included in the book might be of some help to the readers in getting an idea about the messages and pointers provided by them. The conference background paper, the centre-piece of the book, by C.S. Venkata Ratnam is a concise over- view of the debate to which the book relates. It looks at various facets of the influence of New Economic Policy (NEP) on the functioning and developments of ITUM. This thematic paper is followed by a synoptic overview by Venkata Ratnam and Pravin Sinha of some of the major points raised in the conference. While explaining the employment situation in India, T.S. Papola, known for his contribution in employment related matters, states that since independence the growth in employment has been low because of increase in labour force and low economic growth. Underemployment of capital and human resources and their low productivity have been character of Indian unorganized sector.

The broad policy guidelines of the NEP, the subject matter of most of the papers, according to N.R. Seth, imply that industrial activities should be promoted with minimum regulation and control by the state. Structural adjustment has come to acquire a negative connotation because, according to Venakata Ratnam, its rationale, intent, content, process and outcome have been misunderstood, misrepresented and misinterpreted by both those who are at the giving and at the receiving end of the prescription for it. Its most worrisome indicators are the short fall in job creating and rise of inflation, argues Venkata Ratnam. Ishwar Dayal stresses that the role of trade unions does not change with the changing economic scenario but the trade unions and their objectives have to be seen in proper perspective and be attuned to the interests of the working class. Vinayshil Goutam in his paper argues that whereas the concept has undergone a sea of change, the meaning of workers has remained constant. The trade unions, comments J.M. Sampath, are caught in the dilemma of "to accept or not to accept the process" as both being equally difficult. 
Falling in line with the international tide, India has witnessed a substantial fall in its union membership base of similar dimension to that seen in most other countries. Almost all the papers in the present volume point to declining trade union trend in the country. K. Mamkootam, while attempting to unravel the industrial relations strategies adopted at the state and enterprise level in the context of globalization of the Indian economy, indicates the declining power of trade unions and also projects the declining trends in their membership. Sarath Davala's paper speaks of the nonexisting unions in the unorganized sector and the need for ITUM to bring them under its fold. Yet another case on much talked about Kanoria Jute Mills (KJM) turnaround experiment, by Botterweck and Sinha, clearly shows how the management could ignore all the unions at Kanoria.

Most of the papers have made a pointed reference to the growing ineffectiveness of trade unions in India, more so of their federations at the state and national levels. Many of the unions, as a consequence, are reported seeking deaffiliation from the politically linked CTUOs. Seth argues that protests and threats issued by trade unions have had negative impact specially on people outside trade unions who are regarding such a negative attitude of trade unions against NEP unjustified. Davala too opines that the ITUM is deeply fragmented along many lines on matters not even connected with workers and their welfare, resulting in its incapacity to assist itself.

The papers presented and the deliberations held during the conference seem to have clearly demonstrated that the changes brought about in Indian economy by the NEP have put varied demands on the ITUM which in its present character is incapable to handle. Proposing a workable agenda for action in preparing trade unions in meeting the emerging challenges, Venkata Ratnam, in his paper, advises the Indian trade unions to first understand not only the implications of change but also of non-change and nonadoption. There is an urgent need for trade unions to critically look within and adopt suitable changes so as to fully integrate in the changing environment and also adopt new policies and programmes more attuned to the current situation. Trade unions, in order to be effective in the new economic regime, have no alternative but to fight together says Davala. Botterweck and Sinha also feel that under the new economic environment unity amongst the trade unions is not merely an ideal but a necessity and, perhaps, the only way to sustain and keep the movement alive. Citing the examples of $\mathrm{KJMs}$, most of the papers, featured in the book, have shown hollowness of their strategies adopted by the trade unions as also of their leaders. The trade unions need to adopt policies to integrate them more in the community, as their power base is people who are a part of the community, suggest Dayal. Their actions should be such that the overall interest of the community is not in conflict. While fighting for the cause of working class, he argues, the trade unions ought not forget the overall interest of the enterprise which is, in fact, the basis for their existence and continued survival. Gautam also feels that the times demand a redefinition of the contours of trade union movement and realignment of the variables within it. Seth invites government, industry and trade unions to reflect on their share of responsibility to achieve the central mission of NEP. Sampath and Dubey, while addressing to some basic questions regarding the present state of Indian trade unions, also call for a basic shift in the values and beliefs of management and unions while dealing with each other in the context of new economic environment.

All the papers contained in the book (most of them already published in one form or the other) taken together make an excellent reading and a useful contemporary contribution. References to the 
developments across nations, however, would have been an additional feature. Further, the depletion in union ranks is attributed to a host of factors (in addition to those highlighted in the book) including the growing service sector and the rise of HRM. For example, a number of companies in India (Ponds, Modi Xerox, Enfield, Wipro and Nirma to mention a few) are increasingly adopting a variety of softer HRM strategies to marginalize the union influence, others are pursuing aggressive union exclusion policies. The contributors to this volume seem almost oblivious to these developments. Moreover, spelling mistakes should have been more professionally managed. A careful proof reading would have increased the strengths of the book. The absence of index (subject or author) at the end is also a serious limitation. In some places, references are incomplete and lack consistency and uniformity. One also notes variation in the level of analysis and lack of uniformity in the aims, contents, approach and presentation of the papers. There are too many repetitions of same ideas and events in different parts of the book, a common feature of almost all conference volumes.

These observations are, however, not meant to detract from the considerable achievements of the book; rather these should be taken as suggestions for future publications of FES and others in this complex and rapidly evolving field. These gaps are almost inevitable given the nature of such a volume.

On the whole, in every paper a great deal of painstaking research work has been done and every paper contains a quarry of facts and messages which researchers in the field can profitably mine. The book does not have all the answers and like all good books it raises more questions than answers but it is an excellent antidote to the ever increasing number of IR/HR texts that invariably fail to provide different dimensions of the changing nature of labour management relations. The chief merit of the book lies in its excellent get up. The authors and editors need to be commended for making effective use of the available material by drawing on their rich experience as observers of the developments in industrial relations. The volume under review is yet another evidence of their enviable command on their chosen field of scholarship.

The volume is of much theoretical and practical significance to public policy makers, managers, union leaders and academicians not only in India but also in other countries undergoing transformation. Kudos to FES for having brought out such an innovative and timely collection for wider availability. One must admire them also for producing nicely a book which runs the risk of becoming rapidly out of date; such is the movement of changes in industrial relations at present. It is difficult to do justice with all the merits of the book in such a short review. My advise to anyone interested in this area is to read the book at the earliest opportunity.

ABDUL GANI University of Kashmir 